\title{
Why the Life of Heaven is supremely worth living
}

\begin{abstract}
Richard Swinburne
[Swinburne, Richard, 2017, 'Why the Life of Heaven is supremely worth living' in (ed.) T.Ryan Byerley and Eric J.Silverman, Paradise Understood: New Philosophical Essays about Heaven, Oxford University Press.]

Abstract: In this paper shall develop widely held intuitions about what makes a life a good life to live, and so what would make a life the best sort of life to live forever; and I shall then argue that the kind of after-life to be enjoyed by the Blessed as described in patristic thought, is just that sort of life.
\end{abstract}

\section{I}

Enjoyment consists in being in a situation where you desire (or in the modern sense 'want') to be, to have the feelings, desires, and beliefs which you desire to have, and to be doing an action which you desire to be doing. And it is of course good to enjoy life, to be happy - so long as you are not getting your enjoyment from having feelings of hatred or other bad feelings, or from false beliefs or from doing what is morally wrong. But, as most people realize, there is more to a worthwhile life than enjoyment.

It is good to have true beliefs and correct feelings. It is good to have true beliefs (which I shall call merely 'knowledge') about anything but especially about what is intrinsically good or bad, and about the causes of intrinsically good or bad states, and more generally about deep moral, metaphysical, aesthetic and scientific matters (which may be articulated in appreciation of literature and other arts rather than in precise philosophical terminology). It is good to have good desires - for the well-bring of all humans (and animals), and especially for those close to us, and for ourselves. It is a good to have correct feelings - of love for all humans, and so of sympathy for those suffering, of affection for those friends who have interacted with us in important ways over a long time (and especially our parents and children), or grief at the deaths of such friends, of sorrow at the failure of their projects, of anger at wrongdoers. It is good to have significant powers, powers (and so opportunities) to make differences to oneself, others, and the world. To be of no use to anyone is tragic. It is good to have respect for all people - especially for the good and wise and powerful. It is good to feel respect for all persons for what is good in them, and so especially for morally good 
persons, but also for those who have great wisdom, power and responsibility - since having great wisdom, power and responsibility would be a great good in us, it is great good in anyone else - so long as they exercise their power wisely. It is good to have feelings of gratitude to those who have given us much and therefore especially (let us hope, in most cases) our parents and teachers. And it is good to love and to be loved, and so to need someone else and to be needed by them; and for all the good things that we have, it is always better if the good thing is given to us out of love. And it is good for us if there is at least one good person who cares for us and also knows all about us, and so can help us to become a good person.

While it is good for us to have fulfilled desires, right attitudes, and significant powers, it is a basic intuition that what we do with our powers and especially what we do successfully, contributes more to the goodness of our life than what happens to us. Our actions are better, the better their goals, and the more those goals take time and energy to achieve. We have special obligations to our benefactors and especially to our parents who are to some small degree the cause of our existence, and - if they are also nurturing parents - to a larger degree for all their actions of feeding and nurturing us. We have special obligations to spouses who have promised us their lifelong loyalty; and special obligations to our children whom we have caused to exist in an initial condition of total impotence. And we have lesser obligations to those who have benefitted us in lesser ways, including simply by cooperating with us at work or having a friendly conversation with us. It is good that we should not merely feel, but show the respect due to the good who have great wisdom, power and responsibility. Good actions also include the best actions of all, supererogatory actions, actions 'beyond the call of duty', actions of doing more than we are obliged to do - caring for the parents and educating the children of others, and sacrificing our own life (not merely some time and energy) to save the life of someone else. It is very good to too write novels, poems and plays, play music, paint pictures, and develop our understanding of moral, metaphysical, and aesthetic realities - even if solely for our own benefit, but better of course if others can enjoy our creations. It is good to do these actions spontaneously, out of a natural desire for the well-being of others. It is also good if we do them as an act of libertarian free will, despite desiring not to do them, that is despite contrary temptation. But of course naturally doing good, and doing good despite temptation, while both goods, are incompatible goods. Yet we are so made that by choosing often to do good actions despite contrary temptation, we can gradually make ourselves less inclined to yield to temptation and thereby gradually become people who do good actions naturally. It is good too that we should be able with help from others to work out for ourselves (as well as deep 
metaphysical, aesthetic, and scientific truths) the moral truths what is good and what is bad to do, and in that sense be autonomous. (Given that there are objective moral truths, it is not possible to be autonomous in the sense of 'deciding' which actions are good or bad.) But, as I claimed earlier, it is also good that we should know what is morally good and what is morally bad. And again these are incompatible goods, since we cannot work something out for ourselves if we already know the answer. But given time and honesty, we can, I believe ${ }^{2}$, make some progress in moving from ignorance to knowledge (as well as of metaphysical, aesthetic, and scientific truths) also of moral truths. It is a lot better if our actions succeed in achieving their goal, but is still good to try to achieve a good goal, even if we fail.

If there is a God, these aspects of a good life can be realized in far more and deeper ways than they could otherwise be. It is good, I argued, to seek true moral and cosmic beliefs. Physics may be able to tell us what are the fundamental laws which govern the physical universe (or - if there is one, the multiverse); but if there is no God, the existence of the physical universe (or multiverse) and the operation of these particular laws will simply be a brute fact for which there is no explanation. If there is a God then there will be an explanation of why there is a universe governed by these laws - that the universe is created and sustained by God, and that he made it the way it is because that is a good way for it to be and it makes it possible for us to live in it. And either by our natural reason or because God reveals it, we can discover this explanation. True, there may remain questions to which we will never know the answer - e.g. why there is a God at all - but there will be discoverable answers to some otherwise unanswerable questions.

It is good, I argued earlier, to have good desires and correct feelings. If there is a God, there will be many more good desires and correct feelings to be had, and it will matter a lot more that we should have them, since it matters that we should have good desires and correct feelings towards God. Since it is good to reverence those mildly good persons who have some wisdom, power, and responsibility, it will obviously be very good to have feelings of deep reverence towards God who has total wisdom, power and responsibility, and is the ultimate cause of things. And it is obviously good to have deep gratitude to God for our existence and all the good things in our life ${ }^{3}$, and to have a strong desire to please him who has so generous to us. Further, all the desires and feelings which it is good that we should have towards other humans (and animals) will be good to have for another reason, the reason that God has intentionally made them and continues to sustain them in existence by the same process as he made and sustains us to share the same universe.. They are all therefore in a wide sense our 
brothers and sisters; and so it is even more important than it would be otherwise, that we shall be concerned for their well-being. If we do have the right desires and feelings of these kinds, our life will be significantly better than it would otherwise be.

I argued earlier that while it is good for us to have some good thing, it is always better if the good thing is given to us in an act of love for us. Now our parents may have chosen to have a child, but they did not choose to have us. While laws of nature may determine that the child produced by their intercourse was a child of a certain kind (e.g. with a certain genetic make-up), there are innumerable possible children of just that kind. Only God or (if there is no God) chance could determine which of those possible children their actual child would be. So if there is a God, our life is immediately far better in the respect that it comes to us, not by chance, but by an act of love. I also argued earlier that it is good for us if there is some good person who cares for us and also knows all about us. For so many humans, there is no other human who knows very much at all about their plans and pleasures; and, I suspect, there is no human whose pains and pleasures are fully known by any other human. An omniscient God would know all, including our private thoughts. Atheists sometimes claim that this would only be good if we consent to $i^{3}$. But if we need help to live a good life (and surely we all do) that is only possible if there is someone who knows what our problems are, and is ready to help. It is good for us if a supremely good and all-knowing God who is not merely ready to help, but ready to overcome our foolish resistance to accepting his help; for he can help us only if he knows all about us, more that we are willing for him to know.

It is good, I argued, to need others, and good to be needed by them. If there is a God, we need him to keep us and the good things of life in existence; and he who has created us, like all parents, has taken the risk that we may rebel against him. So, although he did not need to create us, ${ }^{4}$ once having done so, he needs us not to rebel ${ }^{5}$. Needing and being needed encourages love and being loved. And God, like any good parent, will love us whatever we do; and to be loved by the all-good source of our being is an enormous benefit for us. If I hurt your child, I wrong you who have fed, nurtured, and educated her; and so if I wrong any other human, I wrong God who is so much more the source of their existence than are her parents. And if I hurt some other human, I also wrong my parents insofar as they have fed and educated me and taught me how to live; and so again in wronging others, I wrong God because I misuse the power and moral sensibilities of which he is the ultimate source. So if I fail in my obligations to pray and worship, or wrong others, I must repent not merely to those wrongly directly, but also to God for my wasted life. And the Christian tradition assures wrongdoers of God's 
forgiveness, if they seek it by pleading the atoning work of Christ on their behalf, subject to one condition - that we forgive others ${ }^{6}$. Because of that, there is a considerable incentive to the other humans whom I have wronged to forgive me - since God's forgiving them is conditional on their forgiving me. God thus makes it easier for our guilt to be removed.

\section{II}

I have been describing what makes life good; and to some considerable extent life on earth is quite good for many of us. But for many of us, it is far from perfectly good. Many of us suffer from physical pain; our circumstances and disabilities frustrate our good ambitions, we are very ignorant of the truths of morality, of the nature of the universe and of the God who created it. We suffer from bad desires - hatred and greed, instead of love and sympathy for others; and although it is good to have grief and sorrow where it is appropriate, it is bad that it is appropriate - those whom we love and who love us die, and their projects fail. And, as I commented, there are significant limits to how well we know them and they know us. And for so many of us there is no one whom we love at all well and by whom we are loved at all well. It is often difficult for those of us who believe in God to worship him; he seems so often a distant God; he may understand us, but there is so much about him that we do not understand. When we ask him for some good gift, often he does not provide it, nor explain why he does not. Our powers to achieve good are limited, and frustrated by circumstances and death. When we have wronged others, even if we repent and ask them for forgiveness, they do not always forgive us, and anyway they may be dead and unable to do so. It may not even be possible for someone to ask for forgiveness with enough sincere repentance appropriate to a very bad wrong, because they are not the sort of person capable of sincerely repenting for something so wicked ${ }^{3}$. John Hick illustrates the latter by Dostoevsky's fictional example of the general who set his hounds to tear to bits a serf child because the child threw a stone which hurt the general's $\operatorname{dog}^{7}$. Such a wicked person would probably need a far longer period than is available in a life on earth in which gradually to change his character totally in order to be able to show sincere repentance.

So all of that suggest that a good after-life would be one in which all these earthly frustrations are removed. It would be a life without physical pain, and one when we are not subject to bad desires, where we begin to understand the deep truths of morality and metaphysics, where we love others fully and know them deeply, 
and are loved fully and known deeply by others, and where we and they do not die, and where we can do greatly worthwhile action. It would also be a life where those who could not achieve reconciliation on earth, because the wrongdoer was not capable of the requisite sincere repentance, could after a long purgatorial period show that repentance which would make forgiveness and so reconciliation possible. Above all a good after-life would be one where we can know God the source of all other being, interact with him, and worship him far better than we can on earth, and greatly enjoy doing so, and where this action and all other actions are done in cooperation with others. If such a world is to be an everlasting world, where there is no death it must be a world in which we can grow in all these ways. For human well-being consists in growth achieving new things, coming to understand things better and better, coming to know and love others and above all God more and more thoroughly, and to be known and loved by others more and more fully.

I suggest that only that sort of life would be worth having for ever. Only a task which made continued progress valuable for its own sake but which would take infinite time to finish would be worth doing for ever; only a situation which was ever more worth having would be worth living in for ever. The growing development of a friendship with a God who, if he is the sort of God pictured by Christian theology, has ever new aspects of himself to reveal, and the bringing of others into an ever-developing relationship with God, would provide a life worth living for ever, and a person who desired only to do the good would want that sort of life forever. Most earthly occupations indeed pall after a time, but the reason why they pall is that there are no new facets to them which are greatly worthwhile having. A person who desires only the good and its continuation would not, given the Christian doctrine of God, be bored in eternity.

\section{III}

If this would indeed be the best life worth living, then Heaven, as depicted by the fairly unanimous patristic tradition would provide that life. The very large measure of agreement in the patristic tradition about the nature of Heaven is brought out by the very full account of this tradition in B.E. Daley's The Hope of the Early Church $^{8}$, The Fathers all agree that the Blessed (the inhabitants of Heaven) will be free from pain, and suffer no disability; the body will go 'wherever the spirit wills. ${ }^{9}$ They will be freed from bad desires. Augustine wrote that 'there the virtues shall no longer be struggling against any vice or evil. ${ }^{\prime 0}$ But that, he claims, does not deprive the 
blessed of free will. It does however, he acknowledges, deprive them of freedom to choose the bad. In my view, the reason for this, though he does not state it, is that to believe some action good to do motivates us to do it; and so in order to have a choice of doing what we believe bad, people have to be subject to non-rational desires to do what is bad; when freed from these bad desires, and given true moral beliefs and a correct understanding of some situation, the blessed will inevitably do whatever in that situation is the best action to do, if there is one. But if there is no one best action, they will have a choice between two or more or maybe even an infinite number of equal best actions; or perhaps - like God - they may sometimes have a choice between an infinite number of incompatible good actions, each less good than some other one. They may thus have a very considerable range of choice between actions. Indeed if there is an infinite number of individuals whom they can help and a finite limit to the number they can help at any one time, they will have an infinite number of choices. But, all the same, objectors will say, such choices are not nearly as significant as choices between good and bad; and that is surely so. But having free will to choose between good and bad, and spontaneously and naturally doing good are both good states; but - as I pointed out earlier - they are incompatible good states, and no one can have both of them to a maximum degree. And it is surely good for us on earth who have the choice between good and bad, to seek to become the sort of people who do the good naturally. The best arrangement is surely that we shall have a choice by choosing the good so often on earth, of making ourselves so naturally to want to choose the good that God gives us what we want - the freedom from bad desires ${ }^{11}$.

We will come to understand deep truths of science, as well as of metaphysics, theology and ethics. Origen wrote that the blessed 'will see clearly the nature of the stars, one by one, and will understand whether they are living creatures, or whatever may be the truth about them. ${ }^{12}$ Augustine wrote that we shall discern all the interior parts of the body whose nature and interaction 'at present elude our observation', 'together with the other great and marvellous discoveries which shall then kindle rational minds in praise of the great Artificer'; this will lead to 'the enjoyment of a beauty which appeals to the reason'. ${ }^{13}$ Above all God will no longer seem a distant God. We shall 'see' God and know far better what he is like, an awareness of God traditionally called 'the Beatific Vision.' 'Then I shall know fully even as I have been known, wrote St. Paul' ${ }^{14}$. God's servants will worship him; they will see his face', ${ }^{15}$ wrote the author of The Book of Revelation, the one book of the New Testament which tells us much about Heaven. Origen wrote that the heavenly banquet, consists in 'the contemplation and understanding of God' according to the measure 'appropriate and suitable to this nature 
which has been made and created'. ${ }^{16}$ That vision will give us great joy; 'O blessed, thrice blessed, many times blessed are those who will be worthy to look on that glory', wrote John Chrysoston. ${ }^{17}$

All this led some of the early theologians to describe Heaven as involving or leading to 'union with God'; but those who so describe it in this way usually make it clear that God's presence in the saints is 'by his good pleasure'18 and by conformity to his will; our individuality remains. A similar point applies to talk of Heaven as

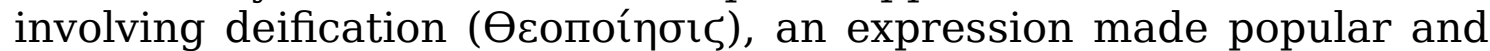
given permanent currency in the Orthodox tradition by St Maximus the Confessor. This does not mean literally 'becoming God', for to be God is to be eternally and necessarily God; rather it is 'enjoying the divine relation of Son to Father, sharing the divine life.' ${ }^{19}$

This awareness of God, so absent from life on earth will make it possible to show him far more fully the respect due to him; and so as Revelation ${ }^{20}$ depicts it - worship will be the central activity of Heaven. Worship will be a cooperative activity. Heaven is a society in which people do things together; Revelation never pictures solitary worshippers. And its favourite metaphor of Heaven as a 'city', Augustine wrote, would have no meaning 'if the life of the saints were not a social life'. ${ }^{21}$ Although that will not be the primary point of Heaven, it will involve renewal of earth's friendships. John Chrysostom suggests that the joy of the blessed will not be complete until they are joined by the whole company of the saved, 'just as a kind father might tell his children, who have worked hard and deserved well, that he will not give them anything to eat until their brothers and sisters come'. ${ }^{22}$ And we shall know each other thoroughly and be known thoroughly by them. The inevitable distance of understanding and so of loving between people on earth will have been overcome. Julianus Pomerius, a priest in Gaul in the late fifth century, wrote that each person will be 'completely transparent, in thought and desire, to all the rest, yet completely without embarrassment. This mutual openness will lead to a divine and reciprocal love' that will bind the citizens of Heaven to each other eternally, as well as to God.' ${ }^{23}$ Honour will be given not merely to God but to each person to whom it is due; it shall be denied to none who is worthy; nor yielded to any unworthy.' ${ }^{24}$ The blessed will help God in his work. Jesus told his disciples 'truly I tell you at the renewal of all things ... you who have followed me will sit on twelve thrones, judging the twelve tribes of Israel.' 25 'Judging' may mean 'ruling over', and Ambrose claims that the apostles will share in the universal rule of Christ. ${ }^{26}$ And a primary occupation of the saints always been supposed to be, to intercede on behalf of others. Jerome consoles bereaved friends by assuring them that their loved ones who have died now enjoy the company of the angels and saints, even while they remain concerned about us on earth and continue to 
intercede for us. ${ }^{27}$ And many church prayers ask the saints not merely to intercede for us, but to help us more generally.

All the Fathers of course claimed that, at least after the General Resurrection, the blessed will be embodied; they claimed this because it was a central Christian doctrine. After all, Jesus rose from the dead in an embodied state, and so it was only to be expected, that the Blessed would be embodied. But 'why must the spirits of the departed be reunited with their bodies in the resurrection, if they can be admitted to the supreme beatitude without their bodies?' (i.e. before the General Resurrection), asked Augustine in De Genesi ad Litteram $^{28}$. And he continued 'this is a problem ... too difficult to be answered with complete satisfaction in this essay'. And I have not found much of an answer to Augustine's question elsewhere in his or other patristic writing. There is however in my view a very powerful reason why God should resurrect humans with bodies. This is that they need to recognise each other and to contact this person and not that person. As I argue elsewhere ${ }^{29}$, what makes a human person the person he is is not his body or his mental or physical properties, but his soul, a mental substance which has 'thisness'; a person's soul having 'thisness' means that his soul is just numerically different from any other soul but not in virtue of having different properties. It follows that humans in Heaven would need contingent publicly accessible (that is in my terminology, physical) properties by which they could recognise each other. Obviously if they manifested in their public behaviour physical properties which showed that they had different mental properties (e.g. although not embodied, they had different voices which publicly recalled different past events), that would help them to recognize each other. But such properties are readily duplicable - it would be easily possible for two persons to recall more-or-less the same events; and we would not readily feel that we were thoroughly in touch with a particular person merely because the person whose voice we heard seemed to recall different events from those which others recalled. Clearly if the Blessed also had public spatially extended physical properties - including both monadic properties (they look different from each other), and relational properties (each looks similar to one and only one former person on earth) - it would be far more obvious, as it is on earth, to whom one was talking. And spatially extended physical properties belong to a person in virtue of belonging to their body. God, having essential properties so different from human properties, which he can manifest publicly, for example by showing the enormous degree of his power and knowledge, and being present everywhere, needs no body in order to be contacted. Other kinds of being, such as angels, if there are such, may have other ways of being contacted, but clearly embodiment provides a way for humans to contact each other. 
I have brought out that fulfilment in Heaven involves actions doing things. But the patristic descriptions of Heaven often speak of it providing 'rest', 'peace', and contemplation rather then action. Cyril of Alexandria writes that it will be 'a life of rest and glory and delight'. ${ }^{30}$ Augustine expects an 'eternal repose not only of the spirit, but of the body'. ${ }^{31}$ Surely part of the joy of knowing God must consist simply in looking at him (with our spiritual vision) in the way that we just look in admiration at a great work of art. But that in the patristic view would be only part of the life of Heaven; as my previous quotations illustrate and as Augustine brings out in his next sentence, 'there we shall rest and see, see and love, love and praise'; 'praise' is an action.

If Heaven is to be fully satisfactory, as I mentioned earlier, it must involve continued growth in knowledge and activity. And some of the Fathers recognized that..$^{32}$ Those who 'follow the way of God's wisdom', wrote Origen, should think of themselves as living in tents, 'with which they always walk and always move on, and the father they go, so much more does the road still to walk grow long and stretch out endlessly .. [the mind] is always called to move on, from the good to the better and from the better to still higher things'. ${ }^{33}$ Our desire for God and so love of him will be ever-increasing. Gregory Nazianzen remarks that seeing God involves 'never to reach satiety in one's desire; one must always look through what is possible to see towards the desire of seeing more, and be inflamed. ${ }^{34}$

\section{NOTES}

1. This essay is partly an expansion of pp. 177-182 of my book Faith and Reason, second edition, Oxford University Press, 2005. Its content overlaps that of a my paper 'The Meaning of Life', in (ed.) S.Goetz and J.Seachris, The Meaning of Life, Bloomsbury Academic, forthcoming.

2. For my account of the necessary nature of fundamental moral truths, and of how we can discover them, see my 'Fundamental Moral Principles', Journal of the American Philosophical Association, forthcoming.

3. Christopher Hitchens posed the rhetorical question, 'Who wishes that there was a permanent unalterable celestial despotism that subjected us to continual surveillance and could convict us of thought crime?' ( The Portable Atheist, Da Capo Press, 1997, Introduction, pxxii). Guy Kahane ('Should we want God to exist?', Philosophy and Phenomenal Research, 82 (2011) 674-96) sees it as a disadvantage if 'even our innermost thoughts' and feelings are not entirely private. For a more thorough presentation of this view, advocating that we should construe God's 'omniscience' as not including knowledge of the private thoughts of humans, see M.Falls-Corbett and F.M.McClain 'God and Privacy', Faith and Philosophy 9 (1992) 369-386.

4. On the Christian view God is a Trinity of persons - Father, Son, and Holy Spirit; and so each member of the Trinity has two others members whom 
he loves and needs, and by whom he is loved and needed. So the whole Godhead did not need to create us in order to be complete.

5. Some theologians will be unhappy with the claim that God 'needs' us not to rebel. But since clearly he desires us not to rebel, then if we do rebel, his desires have been frustrated. And if someone's desires have been frustrated, then they do not have what they need for their complete wellbeing. But of course this need only arises, because by his voluntary action of creating humans with free will, he has voluntarily exposed himself to the risk of having this need.

6. For how the life and death on the Cross provides a sacrifice which sincerely repentant sinners can offer to God as their reparation for their wrongdoing, and how they can offer it to God through faith and baptism, see my Responsibility and Atonement, Oxford University Press, 1989. Jesus taught that God will forgive us in response to such sincere repentance if and only if we forgive others who seek our forgiveness. See for example Matthew 6:14-15.

7. John Hick, Death and Eternal Life, Collins, 1976, pp.161-6.

8. Cambridge University Press, 1991. The subsequent part of this paper is obviously much indebted to Daley.

9. Augustine, City of God 22.30. (translation by Marcus Dods, T and T Clark, 1871).

10. op. cit. 19.10 .

11. 'The first freedom of will which man received when he was created upright consisted in an ability not to sin, but also in an ability to sin; whereas this last freedom of will shall be superior, in as much as it shall not be able to sin' - op. cit. 22.30 .

12. Origen, On First Principles 11.7. (translation by G.W. Butterworth, Harper and Row, 1966).

13. Augustine op. cit. 22.30 .

14. I. Corinthians 13:12.

15. Revelation 22:3-4.

16. Origen op, cit. 2.11.7.

17. John Chrysostom In Joan Hom 12.3, cited by Daley op. cit. p. 109.

18. Theodoret of Cyprus, Commentary on I Corinthians (15.28), cited in Daley op. cit. p. 116.

19. Rowan Williams, The Wound of Knowledge, second ed., Darton, Longman, and Todd, 1990. p. 51, expounding the understanding of this term in 'Origen, Athanasius, and their successors'.

20. See e.g. Revelation 5.

21. Op. cit. 19.5 .

22. In Hebr Hom 28.1, cited by Daley op. cit. p. 109.

23. Julianus Pomerius, paraphrased by Daley op. cit., p. 206.

24. Augustine op, cit. 22.30.

25. Matthew 19:28.

26. See Daley op. cit. p. 100.

27. Daley op. cit. p. 103, citing Jerome Ep 39.2, 7 and Ep 39.7. For Gregory Nazianzen on the work of the saints in intercession, see Daley op. cit. p.88.

28. Augustine, De Genesi ad Litteram 12.35. (translated by J.H. Taylor, Newman Press, New York, 1982).

29. Most recently in my book Mind, Brain, and Free Will, Oxford University Press, 2013. See especially chapter 6.

30. In Joan 10, cited in Daley op. cit. p. 110.

31. Augustine op. cit. 22.30.

32. But not all Fathers recognized it. Clement of Alexandria, over-influenced by Plato's view that the eternal things are changeless, 'denies that the just 
will be capable of progress in knowledge after the resurrection, since all change is characteristic of an earthly, materially circumscribed existence' Daley op. cit. p. 245 note 4, paraphrasing Clement's De Dogmatum Solutione 5.

33. Origen, Homily 17 on Numbers, cited in Daley op. cit. p. 50.

34. Gregory Nazianzen Life of Moses, 2.239, cited in Daley op. cit. p. 88. 